\title{
The first record of the millipede genus Eviulisoma Silvestri, 1910 (Diplopoda: Polydesmida: Paradoxosomatidae) in Cameroon, with descriptions of three new species
}

\author{
Первая находки диплопод рода genus Eviulisoma Silvestri, 1910 \\ (Diplopoda: Polydesmida: Paradoxosomatidae) \\ в Камеруне с описанием трех новых видов
}

\author{
Armand Richard Nzoko Fiemapong ${ }^{1,2}$, Joseph Lebel Tamesse ${ }^{2}$, \\ Didier VandenSpiegel ${ }^{3}$ \\ Арман Ришар Нзоко Фьемапонгі,2, Жозеф \\ Аидье ВанденШпигель
}

\footnotetext{
${ }^{1}$ Laboratory of Zoology, Faculty of Science, University of Yaounde I, P.O.Box 812, Yaounde, Cameroon. E-mail: armandnzoko@gmail.com

${ }^{2}$ Laboratory of Zoology, Higher Teacher Training College, University of Yaounde I, P.O.Box 47, Yaounde, Cameroon

${ }^{3}$ Royal Museum for Central Africa, Collection and data management unit, B-3080 Tervuren, Belgium E-mail: didier.van.den.spiegel (a) africamuseum.be
}

KEY WORDS: millipede, Paradoxosomatidae, first record, new species, Cameroon.

КЛЮЧЕВЫЕ СЛОВА: многоножка, Рaradoxosomatidae, первая находка, новый вид, Камерун.

ABSTRACT. Three new species of Eviulisoma are described from Cameroon: E. subfalcatum sp.n., E. bipartitum sp.n., and $E$. simplex sp.n. These first records of the genus from Cameroon extend its distribution range to central West Africa and confirm the Afrotropical distribution of the genus. A key to all three new Cameroonian species is provided.

How to cite this article: Nzoko Fiemapong A.R., Tamesse J.L., VandenSpiegel D. 2018. The first record of the millipede genus Eviulisoma Silvestri, 1910 (Diplopoda: Polydesmida: Paradoxosomatidae) in Cameroon, with descriptions of three new species // Arthropoda Selecta. Vol.27. No.4. P.278-283. doi: 10.15298/ arthsel. 27.4.02

РЕЗЮМЕ. Описаны три новых вида рода Eviulisoma из Камеруна: E. subfalcatum sp.n., E. bipartitum sp.n., и E. simplex sp.n. Эти первые находки рода в Камеруне расширяют его ареал в центральную часть Западной Африки и подтверждают его афротропическое распространение. Дан ключ для определения всех трех камерунских вилов.

\section{Introduction}

Eviulisoma Silvestri, 1910 is one of the most diverse and widespread endemic Afrotropical genera of the millipede family Paradoxosomatidae Daday, 1889 [Hoffman, 1953; Jeekel, 2003; VandenSpiegel, Golovatch, 2014; Enghoff, 2018]. It belongs to the "ecarinate" paradoxosomatids in which the paranota are very strongly to completely reduced, resulting in their subcylindrical bodies [Enghoff, 2018].

The genus currently encompasses about 60 species or subspecies including those of the genus Eoseviulisoma Brolemann, 1920 recently synonymized by Enghoff [2018], a synonymy previously suggested, but not formalized by VandenSpiegel \& Golovatch [2014]. All described species are known from central (R.D. Congo) and eastern Africa. So far, no species has been reported from the central West African region [Carl, 1909, Hoffman, 1953; Jeekel, 2003; Nguyen, Sierwald 2013; VandenSpiegel, Golovatch, 2014; Enghoff, 2016, 2018].

This work provides the first records of the genus in Cameroon, with descriptions of three new species. A key and a distribution map are provided for these species.

\section{Material and methods}

The materiel underlying the present contribution was collected in lowland forests of Cameroun. All specimens treated here are housed in the collection of the Musée Royal de l'Afrique Centrale (MRAC), Tervuren, Belgium, with a few duplicates donated to the Zoological Museum, State University of Moscow (ZMUM), Russia. The samples are stored in $70 \%$ ethanol. Specimens for scanning electron microscopy (SEM) were air-dried, mounted on aluminium stubs, coated with gold and studied using a JEOL JSM-6480LV scanning electron microscope. The pictures were taken using the 
focus stacking setup as described by Brecko et al. [2014]. It consisted of a Canon EOS 700D, a Canon MP-E 65 mm 1:2.8 1-5x Macro Photo Lens, 2 Yongnuo YN560II flash lights, one remote control for the flash lights, a Cognisys StackShot and an Ikea "Metod" kitchen cupboard. Canon EOS Utility software was used to control the camera. Zerene Stacker was used for stacking the individual pictures into one 'stacked image'.

The gonopodal terminology used in the present work follows that of Enghoff [2018]: solenophore = tibiotarsus; mesal acropodital process and intermediate acropodital process $=$ postfemoral processes.

\section{Taxonomy}

Family Paradoxosomatidae Daday, 1889

Subfamily Paradoxosomatinae Daday, 1889

Tribe Eviulisomatini Brölemann, 1916

Genus Eviulisoma Silvestri, 1910

Diagnosis. In accordance with the terminology updated by Enghoff [2018], the genus Eviulisoma is diagnosed as follows: a genus of Paradoxosomatidae in which the paranota are missing or at most present as tiny keels on ring 2 only; a process (usually) present between the coxae of the fourth male legs; the sternum of body ring 6 is usually deeply excavated; the collum bears two transverse rows of thin setae; postcollar body rings bear only one such row; the gonopod coxa usually has a conspicuous meso-anterior lobe; the gonopod prefemur is shorter than the acropodite, usually less than half as long; the acropodite consists of at least three branches which seem to originate directly from the prefemur; a flagelliform solenomere; a mesal acropodital process which is often the longest of the acropodital branches; sometimes an intermediate acropodital process originating between the mesal acropodital process and the solenomere; a lateral solenophore which serves to protect the solenomere.

\section{Eviulisoma subfalcatum sp.n.}

Figs $1 \& 4$

HOLOTYPE $\sigma^{7}$ (MRAC 22791), Cameroon, Center Region, Zamakoe Forest, $\mathrm{N} 03^{\circ} 33^{\prime}$, E $011^{\circ} 31^{\prime}$, $815 \mathrm{~m}$ a.s.l., forest, 18.IX. 2015, leg. A.R. Nzoko Fiemapong \& C. Oumarou Ngoute.

PARATYPES: $1 \sigma^{7}$ (MRAC 22792), $1 \sigma^{7}$ (SEM, MRAC 22793), same locality same data, together with holotype; 1 O (MRAC 22794), 1 ㅇ (MRAC 22799), 1 ㅇ, 1 f fragment (MRAC 22797), 1 q subadult (MRAC 22798), same locality, 19.IV.2014, 2 우 (MRAC 22796), same data, together with holotype, 1 o

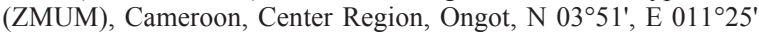
$679 \mathrm{~m}$ a.s.l., 23.IX.2015, all leg. A.R. Nzoko Fiemapong \& C. Oumarou Ngoute.

DIAGNOSIS. This species differs from all congeners by the presence of a well-developed subquadrate paramedian process between the anterior legs of $\sigma^{7}$ sterna 5 and by the subapical part of the solenophore (sph) which is tripartite and showing a short and subspiniform mesal acropodital process (p) reaching the base of a subfalcate lamella process branch of the solenophore (Ip) (Figs 1G, H). See also Key below.

NAME. To emphasize the subfalcate lateral lamella/ process (lp) of the gonopodal solenophore, adjective in neuter gender.
DESCRIPTION. Length of holotype ca $20 \mathrm{~mm}\left(\mathrm{O}^{7}\right)$, of adult paratype ca $21 \mathrm{~mm}(+)$, width of midbody metazonae $1.8-1.9\left(\mathrm{O}^{\top}\right)$ or $2.0 \mathrm{~mm}(+)$. Coloration in alcohol brown to dark brown; metazonae and genae usually light brown; antennae, clypeolabral region light yellow-brown; venter and legs yellowish to nearly pallid.

Body subcylindrical with 20 segments $\left(\mathrm{O}^{\top},{ }^{\circ}\right)$, metazonae only faintly vaulted (Fig. 1A). In width, head $>$ collum=segment $2>3=4-5>6=7-17$; thereafter body gradually tapering towards telson (Fig. 1A). Head above antennae with one seta on each side of the vertex, genae roundish, epicranial suture fine, a little better visible in occipital region; interantennal isthmus about equal to the diameter of antennal socket. Clypeolabral region very densely setose, Antennae medium-sized, only poorly or slightly clavate, reaching behind the posterior margin of metazonae of body segment 3 when stretched dorsally in both sexes (Fig. 1A); in length, antennomeres $1=7<2=3-6$ most subconical; antennomeres 5 and 6 each with a distodorsal compact group of bacilliform sensilla.

Paraterga missing on each side (Fig. 1A). Ozopores well visible on lateral side, rather inconspicuous, lying at ca $1 / 2$ of metazonite length (Fig. 1A). Collum slightly flattened on top $\left(\mathrm{O}^{7}\right)$, with a well pronounced sulcus better visible near dorsolateral margin. Body surface dull to poorly shining, microalveolate to faintly shagreened. Axial line well visible at mid-dorsum. Tergal setae short, largely abraded or missing, traceable only as $1+1$ setae, most well visible on collum and telson.

Stricture dividing pro- and metazonae rather shallow and smooth, pleurolateral keel present on the first 6 segments following the collum, demarcated by a premarginal lateral sulcus, thereafter totally wanting. Hypoproct subtriangular, with $1+1$ caudal setae, the latter being devoid of knobs at base.

Sterna usually without modifications, deeply impressed along axis, densely and finely setose, cross and axial impressions evident; $5^{\text {th }}$ somite with a paramedian subquadrate process between anterior legs carrying numerous setae (Fig. 1E).

Sternite between 6 and 7 segments in $\sigma^{7}$ clearly depressed forming a deep excavation to accommodate the gonopodal telopodite tip (Fig. 1F); anterior margin of excavation with a fringe of long setae. Gonapophyses on coxae 2 well visible $\left(\sigma^{7}\right)$. Gonopod aperture without pecularities. Legs mostly longer (ca 1.4 times as long as body width), each carrying particularly dense setae on ventral side (Figs $1 \mathrm{C}, \mathrm{D})$.

Gonopods (Figs 1F-H) compact, less lamelliform in ventral view. Solenophore (sph) well developed, tripartite in distalmost part, presenting two subequal lamellae and a lateral subfalcate lamellar process (lp) curved mesad at midheight. Mesal acropodital process (p) relatively shorter than solenophore (ca $1 / 2$ of its height), with a spiniform tip, reaching the base of lateral lamellar process of solenophore (Fig. G). Solenomere (sl) flagelliform, reaching (in height) the tip of the subfalcate lateral lamellar process of solenophore (Fig. 1G, H)

REMARKS. Eviulisoma subfalcatum sp.n. is quite similar to other Eviulisoma species regarding most of the somatic characters. Nevertheless, this species can easily be distinguished from its congeners by the gonopodal conformation, in which the solenophore ( $\mathbf{s p h})$ is tripartite, the mesal acropodital process (p) spiniform at its tip and reaching the base of the lateral subfalcate lamellar process of the gonopodal solenophore. 

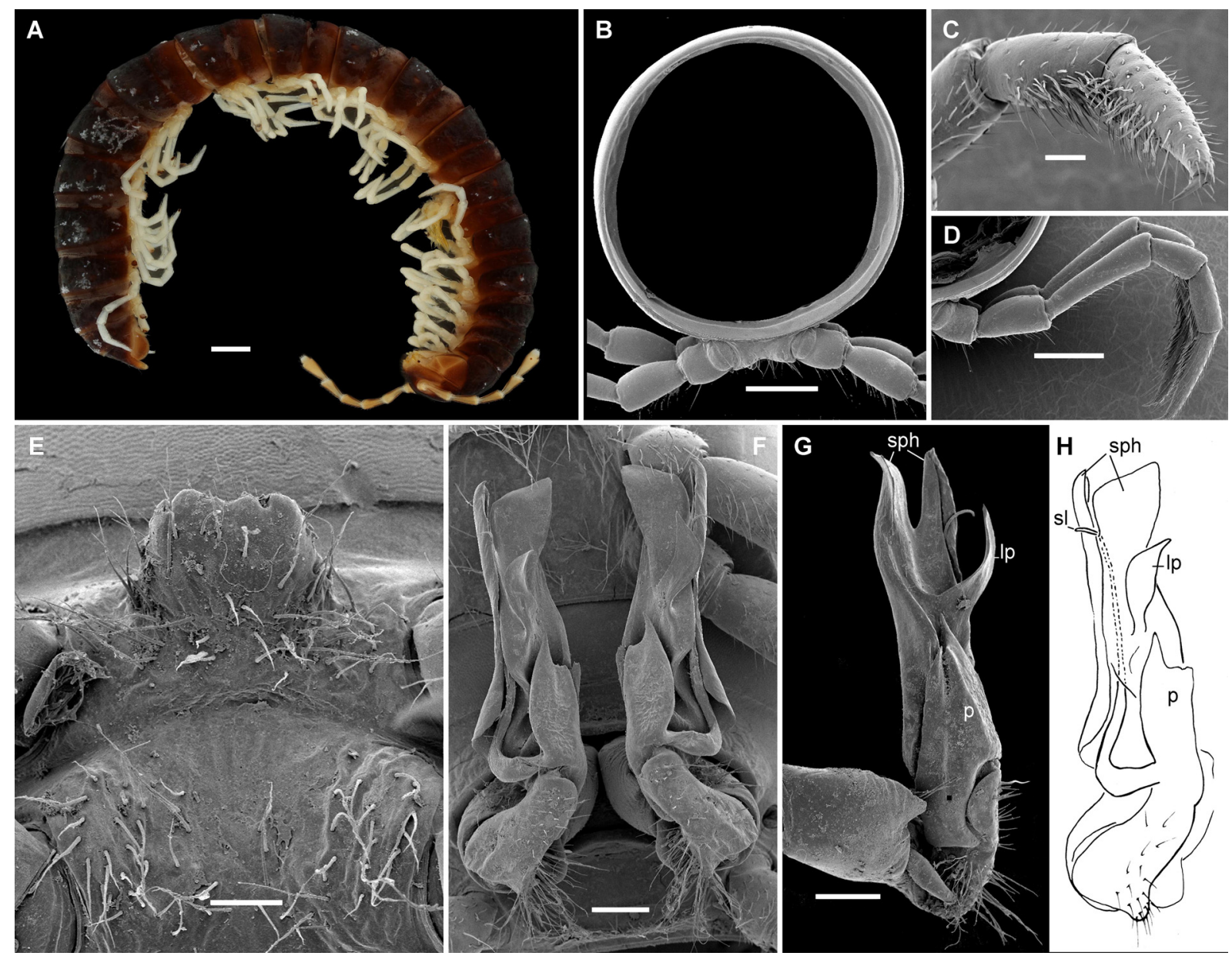

Fig. 1. Eviulisoma subfalcatum sp.n., O paratype (SEM). A — habitus, lateral view; B - cross-section of a midbody segment; C ventral scopulae on tibia and tarsus, lateroventral view; D - midbody legs, oral view; E - sterna on body segment 5 showing the transverse paramedian process; $\mathrm{F}$ - body segments 6 and 7, ventrolateral view; $\mathrm{G}$ - right gonopod, mesal view; $\mathrm{H}$ - left gonopod, ventral view. Scale bars: A $-1 \mathrm{~mm} ; \mathrm{B}, \mathrm{D}-500 \mu \mathrm{m} ; \mathrm{C}, \mathrm{E}-100 \mu \mathrm{m} ; \mathrm{F}, \mathrm{G}-200 \mu \mathrm{m}$.

Pис. 1. Eviulisoma subfalcatum sp.n., паратип О (SEM). А - общий вид, сбоку; В - поперечный разрез среднетуловищного сегмента; C - вентральные щетки на голени и лапке, одновременно сбоку и снизу; D - среднетуловищные ноги, спереди; Е стерниты на туловищном сегменте 5 , показывающие поперечный парамедиальный отросток; $\mathrm{F}$ - туловищные сегменты 6 и 7 , одновременно снизу и сбоку; $\mathrm{G}$ - правый гонопод, изнутри; H — левый гонопод, снизу. Масштаб: A — 1 мм; B, D — 500 мкм; C, $\mathrm{E}-100$ мкм; F, G - 200 мкм.

\section{Eviulisoma bipartitum sp.n. Figs $2 \& 4$.}

HOLOTYPE $\sigma^{7}$ (MRAC 22787), Cameroon, Center

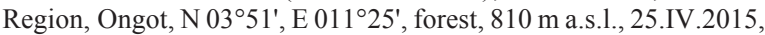
leg. A.R. Nzoko Fiemapong \& C. Oumarou Ngoute.

PARATYPES: $1 \sigma^{7}$ (SEM MRAC 22788), same locality, 14.VI 2014; 1 क (MRAC 22789), same locality, 24.V.2014; $1 \sigma^{7}$ subadult, 1 subadult $\rightarrow$ (MRAC22790); 1 \% subadult, 1 subadult $\sigma^{\gamma}$ (ZMUM), same locality, 26.X.2014; all leg. A.R. Nzoko Fiemapong \& C. Oumarou Ngoute.

NAME. To emphasize the bipartite gonopodal solenophore, adjective in neuter gender.

DIAGNOSIS. Differs from congeners by the conformation of the gonopodal solenophore which is bipartite in the apical part, the lateromesal branch axe-shaped, and the other subtruncated. Mesal acropodital process (p) mostly shorter than in E. subfalcatum sp.n. (Fig. 2D-F).

DESCRIPTION. Length of holotype $\sigma^{7}$ ca $20 \mathrm{~mm}$, width of midbody metazonae ca $1.7 \mathrm{~mm}$. Paratypes (+) $25 \mathrm{~mm}$, width of metazonae $2.1 \mathrm{~mm}$. General coloration in alcohol brown to dark brown (metazonae); antennae, clypeolabral region slightly yellow-brown; legs, venter yellowish to pallid.

Somatic characters as in E subfalcatum sp.n. (Fig. 1A) except as follow.

Interantennal isthmus ca 1.2 times as broad as diameter of antennal socket. Antennae medium-sized, only slightly clavate, reaching behind body segment 2 when stretched dorsally in both sexes. In length, antennomere $2=3>6>5=$ $4>1=7$.

Collum slightly flattened on top $\left(\sigma^{T}\right)$, without sulcus at dorsolateral margin and carrying a little better visible $2+2$ setae on top.

Hypoproct nearly subtriangular, with $1+1$ caudal setae, the latter being devoid of knobs at base. Sterna only slightly impressed along axis. Somite of $5^{\text {th }}$ sterna with a relatively short, subquadrate, paramedian process between anterior legs (Fig. 2C). Legs mostly longer (ca 1.3 times as long as the body width). 

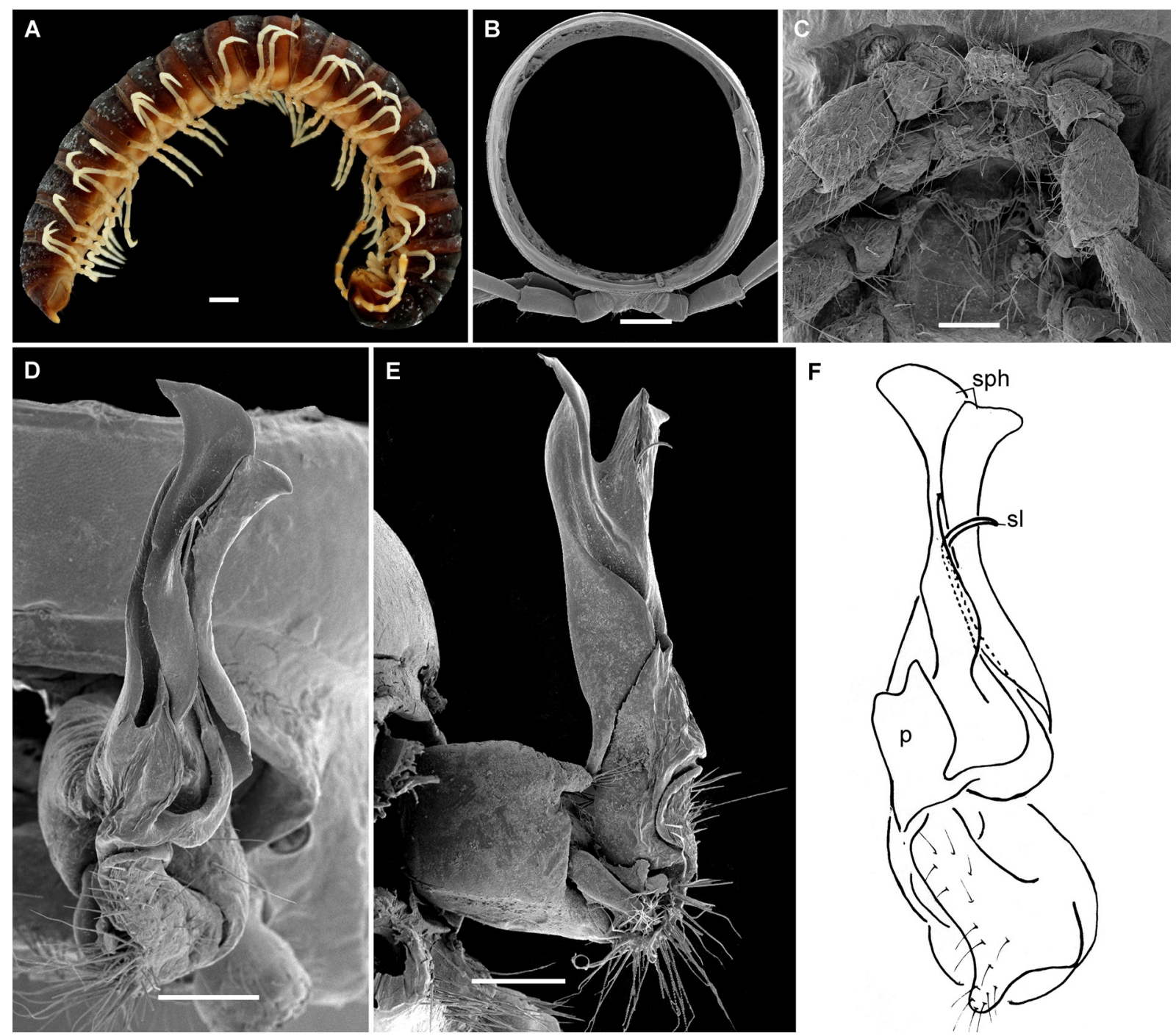

Fig. 2. Eviulisoma bipartitum sp.n. $0^{7}$ paratype (SEM). A — habitus, lateral view; B — cross-section of a midbody segment; C body segments 5 and 6 , ventrolateral views; D — body segment 7 showing right gonopod in ventral view; E — right gonopod, mesal view; $\mathrm{H}-$ right gonopod, ventral view. Scale bars: A $-1 \mathrm{~mm}$ : B $-500 \mu \mathrm{m} ; \mathrm{C}, \mathrm{D}-200 \mu \mathrm{m}$; E $-100 \mu \mathrm{m}$.

Рис. 2. Eviulisoma bipartitum sp.n., паратип О7 (SEM). А - общий вид, сбоку; В - поперечный разрез среднетуловищного сегмента; С - туловищные сегменты 5 и 6 , одновременно снизу и сбоку; D - туловищный сегмент 7, показывающий правый гонопод снизу; Е - правый гонопод, изнутри; Н - правый гонопод, снизу. Масштаб: А - 1 мм: В - 500 мкм; С, D - 200 мкм; Е - 100 мкм.

Gonopods (Figs 2D-F) compact in lateromesal view; solenophore (sph) divided into two parts in apical region, mesal part slightly longer than lateral one and forming an axe-shaped structure in ventral view; the lateral branch of solenophore subtruncate and present a notch. Mesal acropodital process (p) short, spiniform at tip, solenomere (sl) relatively long, flagelliform and well visible in ventral and lateromesal views (Figs 2D-F).

REMARKS. The peripheral characters and the conformation of the gonopods seem to bring Eviulisoma bipartitum sp.n. especially close to E. subfalcatum sp.n. and $E$ congicolens (Chamberlin, 1927) from Congo. Yet E. bipartitum sp.n. can easily be distinguished from the others by the mesal acropodital process longer in E. congicolens, moderate in E subfalcata sp.n. and shorter in E. bipartitum sp.n. Indeed the subapicolateral unciform process found in the solenophore of E. subfalcatum sp.n. is absent in E. bipartitum sp.n. while the solenomere itself is shorter.

\section{Eviulisoma simplex sp.n.}

Figs $3 \& 4$.

HOLOTYPE $O^{7}$ (MRAC 22775), Cameroon, Center Region, Zamakoé, $\mathrm{N} 03^{\circ} 33^{\prime}$, E $011^{\circ} 31^{\prime}$, forest, $810 \mathrm{~m}$ a.s.l., 19.IV.2014, leg. A.R. Nzoko Fiemapong \& C. Oumarou Ngoute.

PARATYPES: 10 (MRAC 22776), same locality, same date; $1 \sigma^{7}$ (MRAC 22777), $1 \sigma^{7}$ (ZMUM), same locality, 18.IV.2015; 1 $O^{7}$ (SEM, MRAC 22779), 1 ㅇ ( MRAC 22780), 2 우 (MRAC 22781), same locality, 19.IV.2014; $10^{7}$ (MRAC 22782), 1 ㅇ (MRAC 22783), 1 q (MRAC 22784), 21.III.2015, 1 q (MRAC 22785), 16.V.2015; 2 क+(MRAC 22786), 19.IV.2014, same locality, all leg. A.R. Nzoko Fiemapong \& C. Oumarou Ngoute.

NAME. To emphasize the simplicity of the gonopod, noun in apposition.

DIAGNOSIS. Differs from all congeners by the relative simplicity of gonopodal conformation in which the solenophore (sph) slightly surrounds a mesal acropodital process 

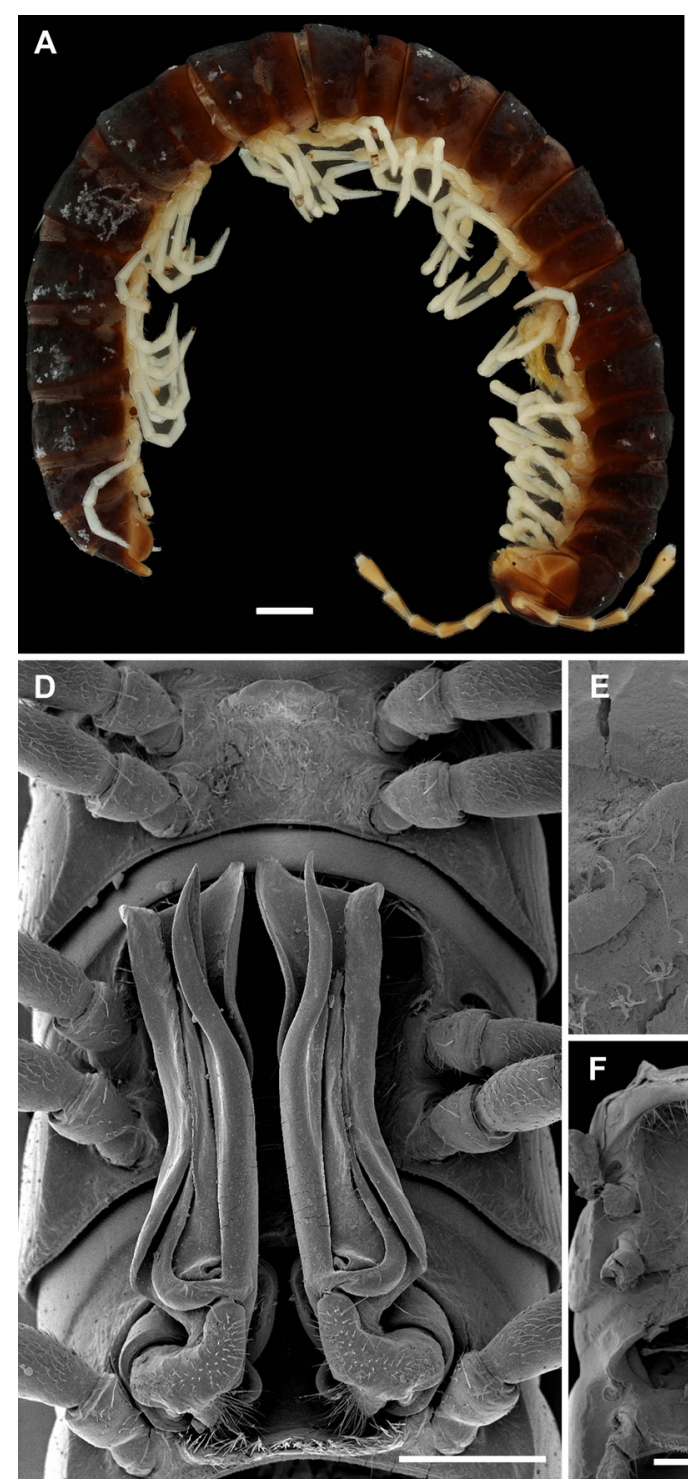
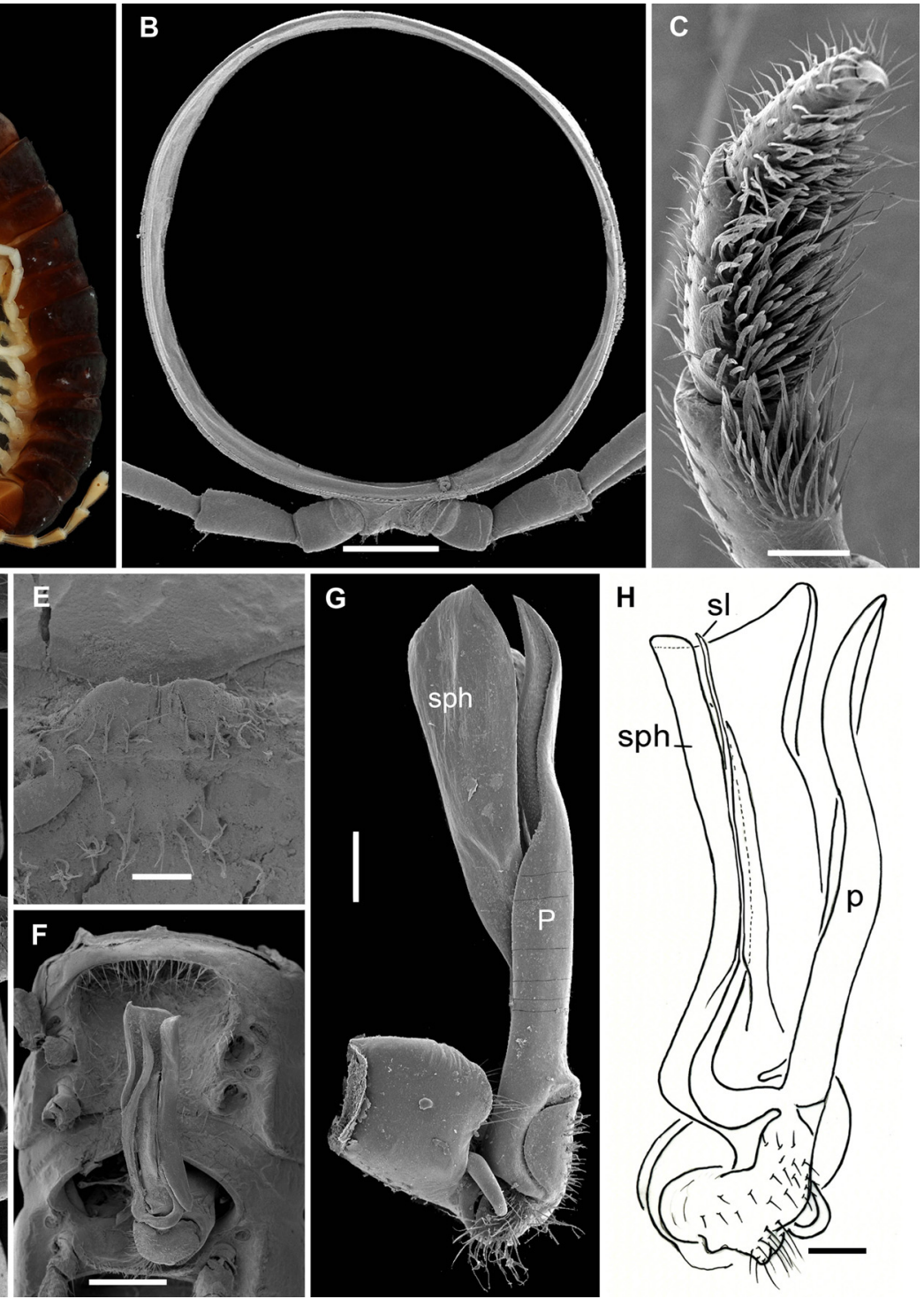

Fig. 3. Eviulisoma simplex sp.n. $\sigma^{7}$ paratype (SEM). A — habitus, lateral view; B — cross-section of a midbody segment; C - detail of three last segments of legs showing a field of scopulae; D - body segments 5-7, ventral view; F, - body segments 6 and 7 , ventrolateral view; E, - sterna of body segment 5, ventral view; G, - left gonopod, mesal view; H — right gonopod, ventral view. Scale bars: A — 1 $\mathrm{mm} ; \mathrm{B}, \mathrm{D}-500 \mu \mathrm{m} ; \mathrm{C}-100 \mu \mathrm{m} ; \mathrm{E}, \mathrm{H}-200 \mu \mathrm{m}$.

Рис. 3. Eviulisoma simplex sp.n., паратип О (SEM). А - общий вид, сбоку; В - поперечный разрез среднетуловищного сегмента; C - детали строения трех последних члеников ног, показывающие поле щеток; D — туловищные сегменты 5-7, снизу; $\mathrm{F}$ - туловищные сегменты 6 и 7, одновременно снизу и сбоку; E - стерниты туловищныого сегмента 5, снизу; G - левый гонопод, изнутри; Н - правый гонопод, снизу. Масштаб: А - 1 мм; В, D - 500 мкм; C - 100 мкм; Е, Н - 200 мкм.

(p), both of them being equal in height, the mesal acropodital process slender, sinuous and knife-shaped in the subapical part. The solenomere (sl) is flagelliform, equal in height to the solenophore (Figs 3G, H).

DESCRIPTION. Length of holotype $\sigma^{7}$ ca $18 \mathrm{~mm}$, width of midbody metazonae ca $1.8 \mathrm{~mm}$. Paratypes ca $19 \mathrm{~mm}\left(\sigma^{7}\right)$ and $22 \mathrm{~mm}(+)$ width of midbody ca $1.7-1.8\left(\bigcirc^{7}\right)$ or $2 \mathrm{~mm}$ (+). Coloration in alcohol brown, prozonae and genae usually light brown; antennae, clypeolabral region light yellowbrown; venter and legs yellowish to nearly pallid.

Somatic characters as in the previous species, except as follow.
Head above antennae faintly rugulose, rather smooth. Vertex with one pair of setae. Interantennal isthmus ca 1.2 to 1.3 times as broad as diameter of antennal socket. Antennae medium-sized, only slightly clavate, reaching behind the middle of body segment 2 when stretched dorsally. In length, antennomere $1=7<2=3<4=5=6$.

In width, head $=$ segment $2=3<$ collum $<4=5-17$; thereafter body gradually tapering towards telson. Pleural keels only faintly visible on body segments 2 to $7^{\text {th }}$ in both sexes. Body surface shining, faintly rugulose. Sterna of segment 5 with a relatively short and large paramedian process between anterior legs (Figs 3D, E). Sterna between $\sigma^{7}$ coxae 6 


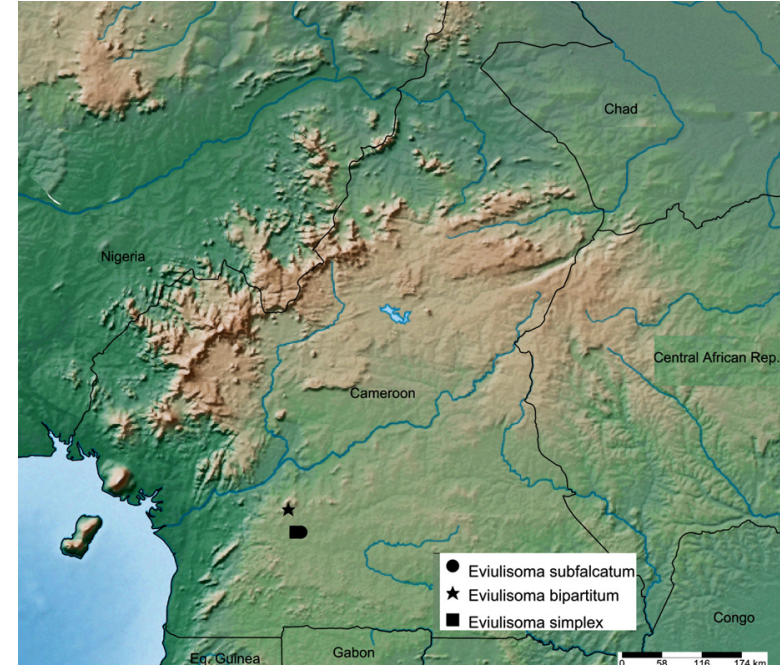

Fig. 4. Distributions of Eviulisoma species in Cameroon.

Рис. 4. Распространение видов рода Eviulisoma в Камеруне.

and 7 usually deeply excavate to accommodate gonopodal telopodite tip (Figs 3D, F), frontal edge of excavation being densely setose (Fig. 3F).

Gonopods (Figs. 3D-F) mostly compact; solenophore (sph) slightly surrounding a long, slender, knife-shaped, mesal acropodital process (p) in subapical part. Solenomere (sl) long, flagelliform and equal in length to both solenophore (sph) and mesal acropodital process (p).

REMARKS. The peripheral characters bring E. simplex sp.n. close to $E$ subflcatum sp.n. and E. bipartitum sp.n. except for the height of the paramedian process on the sterna of body segment 5 which is most pronounced in $E$. subfalcatum sp.n. and less strong in E. bipartitum sp.n.; and with the deepest excavation on the sterna of segment 6 in $E$ simplex sp.n. Nevertheless, the males of this trio can easily be distinguished by the structure of the gonopodal telopodite; the end of the solenophore slightly surrounding the long, slender, knife-shaped, mesal acropodital process (p) in the subapical part in E simplex sp.n., bipartite in E. bipartitum sp.n. and tripartite in E. subfalcatum sp.n. In view of the similarity of the gonopodal telopodite, E. simplex sp.n. is relatively close to E. iuloideum (Verhoeff, 1941) with the long mesal acropodital process (p) well or slightly surrounded by the solenophore (sph). However, there is no articulation on the gonopodal acropodite in E. simplex sp.n. Likewise, the mesal acropodital process is cylindrical in E. iuloideum and subsinuous, knife-shaped in E. simplex sp.n.

Key to EVIUlisoma SPeCies KNOWN to OCCUR IN CAMEROON (BASED ON $O^{7}$ CHARACTERS)

1(2) Mesal acropodital process of gonopod telopodite (p) evident, tip of the latter well to slightly spiniform and either attaining the midlength of solenophore (sph) or not (Figs 1G-H, 2 D-F) ......................................... 3

2(1) Postfemoral process of gonopod telopodite of gonopod well developed, almost equal in length to solenophore (Fig. 3D, F-G) E. simplex sp.n.

3(4) Solenophore of gonopod telopodite bipartite (Fig. 2DF) ........................................... E. bipartitum sp.n. 4(3) Solenophore of gonopod telopodite tripartite (Fig. 1GH). E. subfalcatum sp.n.

\section{Conclusion}

The vast range of the genus Eviulisoma in tropical Africa confirms the global distribution pattern of the family Paradoxosomatidae [Nguyen, Sierwald, 2013]. Several species of this genus are capable of sharing not only the same area, but even the same habitat [Jeekel, 2003; Nguyen, Sierwald, 2013, VandenSpiegel, Golovatch, 2014; Enghoff, 2018]. This concerns also E. subfalcatum sp.n. and E. simplex sp.n. which seem to be sympatric or even syntopic (Fig. 4). This is the case of several species of this genus described from East Africa [VandenSpiegel, Golovatch, 2014; Enghoff, 2018]. Regarding the distance separating the prospected area where the new species were recorded $(<100$ $\mathrm{km}$ ), it is certain that in the near future the number of species of this genus will increase with the prospection of new forested areas in Cameroon.

Acknowledgments. The first author is greatly obliged to the Belgian Cooperation through the ABIC program and the MRAC administration for the financial support rendered to make this research possible. He is also grateful to Mr. Charly Oumarou Ngoute for the assistance in the field. We are most grateful to Sergei Golovatch for his suggestions to improve the manuscript. Special thanks go to Jonathan Brecko for taking the colour pictures and to Christophe Allard for his technical help.

\section{References}

Brecko J., Mathys A., Dekoninck W., Leponce M., VandenSpiegel D., Semal P. 2014. Focus stacking: Comparing commercial top-end set-ups with a semi-automatic low budget approach. A possible solution for mass digitization of type specimens // ZooKeys. Vol.464. P.1-23.

Carl J. 1909. Diplopoden. Reise von Dr. J. Carl im nördlichen central-afrikanischen Seengebiet // Revue suisse de Zoologie. T.17. P.281-365.

Enghoff H. 2018. A mountain of millipedes VII: The genus Eviulisoma Silvestri, 1910, in the Udzungwa Mountains, Tanzania, and related species from other Eastern Arc Mountains. With notes on Eoseviulisoma Brolemann, 1920, and Suohelisoma Hoffman, 1963 (Diplopoda, Polydesmida, Paradoxosomatidae) // European Journal of Taxonomy. T.445. P.1-90. https:// doi.org/10.5852/ejt.2018.445

Enghoff H., Hoffman R.L., Howell K.M. 2016. Checklist of the millipedes (Diplopoda) of Tanzania // Journal of East African Natural History. Vol 105. No.1. P. 51-113.

Hoffman R.L. 1953. Scolodesmus and related African millipede genera (Polydesmida: Strongylosomidae) // Proceedings of the Biological Society of Washington. T.66. P.75-84.

Jeekel C.A.W. 2003. African Paradoxosomatidae, 1: Genus Eviulisoma Silvestri (Diplopoda, Polydesmida) // Myriapod Memoranda. T.6. P.46-88.

Nguyen A.D., Sierwald P. 2013. A worldwide catalog of the family Paradoxosomatidae Daday, 1889 (Diplopoda: Polydesmida) // Check List. Vol.9. No .P.1132-1353.

VandenSpiegel D., Golovatch S.I. 2014. The millipede genus Eviulisoma Silvestri, 1910 in Kenya, with descriptions of new species (Diplopoda, Polydesmida, Paradoxosomatidae). // ZooKeys. Vol.459. P.11-34. doi: 10.3897/zookeys.459.8621.

Responsible editor S.I. Golovatch 